\author{
Abstracta Iranica \\ Abstracta Iranica Revue bibliographique pour le domaine irano-aryen \\ Volume 37-38-39 | 2018 \\ Comptes rendus des publications de 2014-2016
}

\title{
Christophe Benech, Rémy Boucharlat "Organisation spatiale du parc de Pasargades »
}

\section{Astrid Nunn}

\section{(2) OpenEdition}

\section{Journals}

Édition électronique

URL : http://journals.openedition.org/abstractairanica/42599

DOI : 10.4000/abstractairanica.42599

ISBN : 1961-960X

ISSN : 1961-960X

Éditeur :

CNRS (UMR 7528 Mondes iraniens et indiens), Éditions de l'IFRI

Référence électronique

Astrid Nunn, «Christophe Benech, Rémy Boucharlat « Organisation spatiale du parc de Pasargades » », Abstracta Iranica [En ligne], Volume 37-38-39 | 2018, document 13, mis en ligne le 10 mars 2018, consulté le 26 septembre 2020. URL : http://journals.openedition.org/abstractairanica/42599; DOI : https://doi.org/10.4000/abstractairanica.42599

Ce document a été généré automatiquement le 26 septembre 2020

Tous droits réservés 


\title{
Christophe Benech, Rémy Boucharlat « Organisation spatiale du parc de Pasargades »
}

\author{
Astrid Nunn
}

\section{RÉFÉRENCE}

Christophe Benech, Rémy Boucharlat " Organisation spatiale du parc de Pasargades », in Eric Morvillez (éd.). Paradeisos. Genèse et métamorphose de la notion de paradis dans

l'Antiquité (Orient et Méditerranée-Archéologie 15), Paris, de Boccard, 2014, p. 61-72.

1 Après les données textuelles les A. présentent les données archéologiques de Pasargades, où se trouve l'unique "paradis" attesté en Perse. Ils résument les recherches antérieures pour ensuite les confronter aux leurs. Dans le jardin central, les canaux en pierre dessinent deux rectangles semblables qui sont eux-mêmes entourés sur trois côtés d'un second réseau de canaux. Ils sont rythmés tous les 13 à $14 \mathrm{~m}$ par un bassin carré de $90 \mathrm{~cm}$ de côté et $50 \mathrm{~cm}$ de profondeur. Cette installation prouve une maîtrise de l'eau exceptionnelle. Les nouvelles prospections de la Mission francoiranienne de Pasargades ont en outre permis la découverte de nombreuses traces d'aménagement et d'un grand bassin en forme de trapèze au sud-est du jardin central. Tout démontre que le jardin s'étendait bien au-delà des limites supposées jusqu'à présent et qu'il contenait des espèces végétales qui devaient être irriguées. 


\section{AUTEURS}

\section{ASTRID NUNN}

Université de Munich 